Original paper

\title{
Reconstruction of eroded monogenic Strombolian cones of Miocene age: A case study on character of volcanic activity of the Jičín Volcanic Field (NE Bohemia) and subsequent erosional rates estimation
}

\author{
Vladislav RAPPRICH ${ }^{1,2}$ *, Vladimír CAJZ ${ }^{3}$, Martin KOŠŤÁK², Zoltán PÉCSKAY4, Tomáš \\ ŘíDKOŠIL ${ }^{5}$, Pavel RAŠKA ${ }^{6}$, Miroslav RADOŇ ${ }^{7}$
}

\author{
${ }^{1}$ Czech Geological Survey, Klárov 3, 11821 Prague 1, Czech Republic; rapprich@sopky.cz \\ ${ }^{2}$ Faculty of Science, Charles University, Albertov 6, 12843 Prague 2, Czech Republic \\ ${ }^{3}$ Institute of Geology, Academy of Sciences of the Czech Republic, Rozvojová 269, 16502 Prague 6, Czech Republic; cajz@gli.cas.cz \\ ${ }^{4}$ Institute of Nuclear Research, Hungarian Academy of Sciences, Bem tér 18/C, H-4001 Debrecen, Hungary \\ ${ }^{5}$ Museum of the Bohemian Paradise in Turnov, Skálova 71, 51101 Turnov, Czech Republic \\ ${ }^{6}$ Faculty of Science, J.E. Purkyně University, České mládeže 8, 40096 Ústí nad Labem, Czech Republic \\ ${ }^{7}$ Regional Museum Teplice, Zámecké nám. 14, 41513 Teplice, Czech Republic \\ * Corresponding authors
}

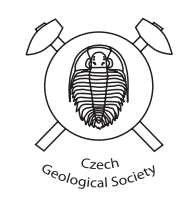

Relics of solitary volcanic edifices in NE Bohemia were newly interpreted as remnants of scoria cones and their conduits. Volcanic activity in this area occurred in a form of scattered Strombolian eruptions of basanitic magmas mostly ascending along E-W trending faults. Nearly all studied volcanoes erupted in similar style, Strombolian, mostly not producing larger lava flows. This volcanic activity took place mainly during Miocene (24.6-16.5 Ma). The lavas known on the Kozákov Hill were produced by much younger volcanic activity (6.7-3.5 Ma) and one of the studied locations is supposed to represent their feeder. The older Strombolian cones are relatively weakly affected by weathering processes. The erosional level at individual sites depends on geomorphology. On some of the edifices non-welded, poorly stratified scoriae are well preserved, at other sites a basal facies or upper vent facies were exposed by selective erosion. Interpretation of the exposed facies with the use of radiometric data brought new insight in relief evolution of this area. Erosion of Cretaceous marine deposits was very intensive during Oligocene, whereas during the last 17 M.y. only some $70 \mathrm{~m}$ of weak sediments were eroded.

Keywords: cinder cone, Strombolian eruption, volcanic facies, erosion rate, Jičín Volcanic Field, Bohemian Paradise GeoPark Received: 11 June 2007; accepted 20 November 2007; handling editor: E. Jelinek

\section{Introduction}

The cinder, respectively scoria cone, is undoubtedly the most abundant subaerial volcanic form on the Earth (e.g., Cas and Wright 1987). The relatively simple architecture of these forms never attracted attention of scientists, as much as the complex volcanoes have. Moreover, cinder cones are only scarcely preserved in ancient volcanic successions. Their small and weak bodies are commonly very rapidly eroded. The architecture and facies of cinder cones were studied in very young or active zones (e.g., Schmincke 1977; Head and Wilson 1989; Valentine et al. 2005; Martin and Neméth 2006; Risso et al. 2008). Studies of scoria cones older than Pliocene are scarce.

Lower to Middle Miocene (20-16 Ma) scattered volcanism was common on north-eastern margin of the Bohemian Massif (Lower Silesia - e.g., Birkenmajer et al. 2004). Strombolian style of volcanic activity was reconstructed on Sośnica Hill volcano in south-western
Poland, which is similar to the Jičín Volcanic Field, north-eastern Bohemia, in both the age and setting (Awdankiewicz 2005).

Volcanological research in Bohemia is traditionally focussed on the Cenozoic volcanism in the Eger Graben with special attention paid to the České středohoří Volcanic Complex in northern Bohemia. The solitary volcanic bodies penetrating the sediments of the Bohemian Cretaceous basin outside of the Eger Graben have never attracted very much neither petrologists nor volcanologists.

A relatively well-preserved set of Middle Miocene scoria cones and their feeders offering well accessible outcrops is present in the Jičín Volcanic Field, southeast of the Cenozoic Eger Graben (Fig. 1a). The area is incorporated into the Český ráj (= Bohemian Paradise) GeoPark, where these volcanic forms dominate the landscape (Fig. 2). Unfortunately, these volcanoes were poorly studied until now. The present multidisciplinary work aims to fill this long standing gap. 

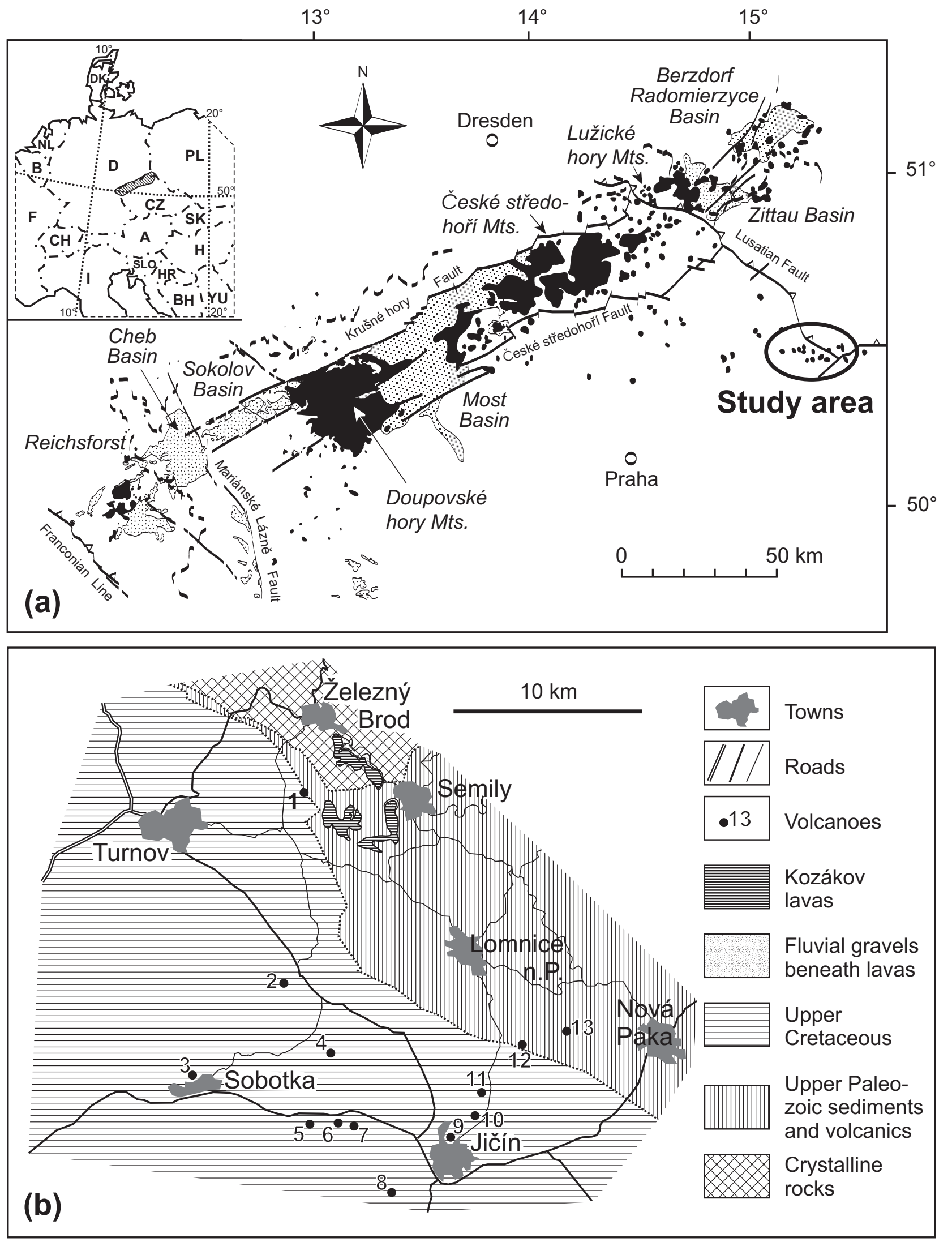

Fig. 1 Location (a) and sketch map of the Jičín Volcanic Field (b). Geological map simplified after Chaloupský et al. (1992), Coubal et al. (1999), Coubal (1999), Tíma et al. (1999); numbers of sites on the map correspond to the text and Tab. 1. 


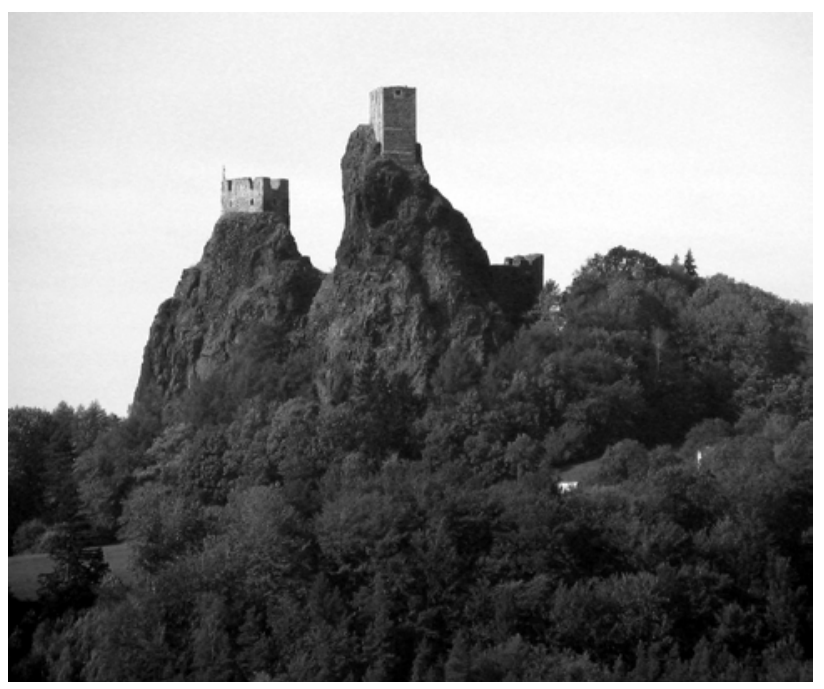

Fig. 2 Trosky: remnant of the 17 Ma old cinder cone with characteristic silhouette is a landmark of the Český ráj area.

\section{Geological setting}

The pioneering studies of Pacák (1947, 1952 and 1959) in the area of Jičín were focused on general information on basaltic rocks, precise location of each individual body and a brief petrographic description. Kopecký (1968) in his diploma thesis studied the setting of basanitic lavas on the Kozákov Hill. Shrbený (1992) presented the first internally consistent dataset of silicate analyses from Cenozoic volcanics of northeastern Bohemia; comprehensive petrological study was carried out by Vaněčková et al. (1993). Study of the circum-Mediterranean region by Lustrino and Wilson (2007) brought some additional analyses from this area, including two radiometric datings.

Several basanitic bodies in northeastern Bohemia carry xenoliths derived from the Upper Mantle (Fediuk 1972). The best-known occurrence of the spinel peridotites with gem-quality olivine in Kozákov lavas was studied already by Farský (1876), more recently by Christensen et al. (2001), Konečný et al. (2006) and Ackerman et al. (2007).

Majority of volcanic bodies present in the region of Bohemian Paradise were traditionally interpreted as volcanic conduits (coherent and clastic ones - „, chimney breccias") exposed by selective erosion (e.g., Coubal 1999; Coubal et al. 1999; Tíma et al. 1999). Although it had been clear enough earlier (esp. in the case of the Trosky Hill), first notes on superficial pyroclastics in this area were presented only six years ago. Rapprich (2001) published a short report on selected volcanic bodies in the Jičín Volcanic Field suggesting the presence of superficial pyroclastic facies at the Zebín Hill. Cajz in Mikuláš et al. (2001) interpreted the Trosky Hill as a pyroclastic cone in an unpublished UNESCO report. Our study focused on the investigation of the eruption style and interpretation of 13 volcanic bodies in the area around the towns Jičín, Sobotka and Turnov (Fig. 1b). Observed appearance of newly interpreted scoria cone and conduit facies in this volcanic field could be also useful for comparison and interpretation of other cinder cones in ancient successions worldwide.

\section{Anatomy of a common cinder cone}

According to the so far published data (e.g., Schmincke 1977; Head and Wilson 1989; Keating et al. in press; Risso et al. 2008), four superficial pyroclastic facies are usually present in a typical cinder cone (Fig. 3). The initial phase, which is often associated with water/magma interaction, produces unsorted xenolith-rich basal phreatomagmatic layer. This initial event may consist of a single or several eruptions, depositing single or several non-stratified beds (Lorenz and Kurszlaukis 2007). The continuing explosive activity, driven solely by magmatic gases, builds the proper cone, consisting of periclinally bedded wall facies in the outer part (e.g., Valentine et al. 2005) and inward bedded crater facies in the inner part. The proximal and distal wall facies could be distinguished using data on differences in dip angle and granulometry. The upper crater facies are commonly non-welded, but locally, they may be also welded. They differ from the wall facies in opposite, i.e. inward dip of bedding and coarser-grained scoria containing cow-dung bombs (some authors - e.g., Sumner et al. 2005 - use the term 'cowpat bombs'). The lower crater facies are commonly strongly affected by alteration due to late magmatic circulation of fluids. The lower crater facies passes continuously into a vent breccia, which already represents subsurface part of the volcanic edifice. Vent breccia consists of juvenile - magmatic - slightly vesiculated fragments of a grain size reaching up to

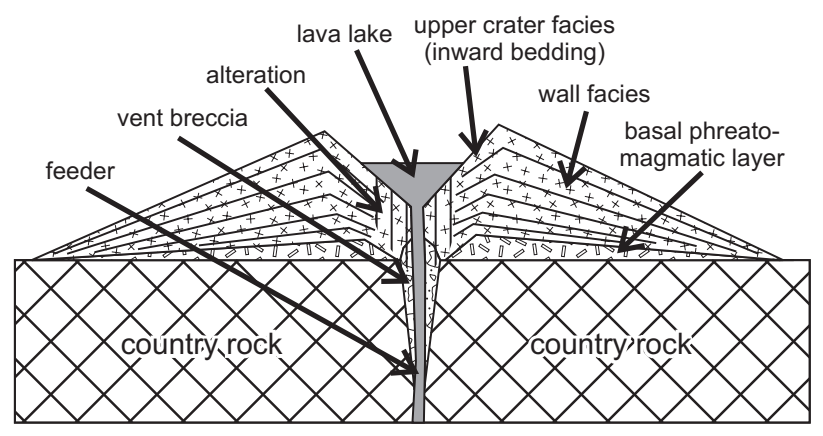

Fig. 3 Distribution of individual volcanic facies in a cinder cone - compiled from Schmincke (1977), Head and Wilson (1989) and this paper. 
$0.5 \mathrm{~m}$. Character of fragments suggests that these were generated by vesicle nucleation and growth from magmatic-gasses saturated magma above the fragmentation level. Later magmatic activity, poor in volatiles, may produce coherent plugs or dykes penetrating the breccia or superficial cone (Keating et al. in press). In some cases, a lava lake may have developed.

\section{The characteristics of the volcanic activity in the Jičín Volcanic Field}

Nearly all the described facies were observed in our study area. The presence of coarse-grained, clast-supported tephras in the scoria cones characterise the volcanic edifices of the Jičín Volcanic Field as "Type 1 scoria cones" sensu Martin and Németh (2006). The small size of the volcanic edifices also fits well the Type 1 cones.

Volcanic edifices consist of volcanic "breccias" penetrated by coherent feeder dykes of limburgite (glassy basanite). These volcaniclastics differ in textures, and individual types were assigned to different facies of the volcanic edifice: non-welded and bedded scoria, nonwelded massive scoria, altered scoria and vent breccias. In the following text, individual facies and their typical occurrences are described in the sequence from the upper ones (less eroded) to the deeper and more eroded parts.

The best-preserved edifice of the Jičín Volcanic Field occurs near Prackov village, SE of Turnov (location No. 1 in Fig. 1 b and Tab. 1). The set of outcrops displays non-welded, unsorted and stratified deposits of basaltic scoriae (Fig. 4) with bedding dipping toward the centre of the body. This trend could be followed around a significant section of this apparatus. The central part of the body is covered by basaltic lava - probably filling the original crater. The grain size of irregular scoria frag- ments varies in the range of $1-10 \mathrm{~cm}$. Altered peridotite nodules form cores of some spindle-form bombs, up to $30 \mathrm{~cm}$ in diameter. The character of pyroclastic deposits and the style of bedding suggest that the upper part of crater facies is preserved and exposed at the Prackov Hill. The age of this occurrence is not determined yet; but the 1) petrology closely comparable to the basaltic lavas of the Kozákov Hill (3.5-6.7 Ma after Shrbený and Vokurka 1985; Lustrino and Wilson 2007), including the presence of similar peridotite nodules, 2) absence of the source vent at the Kozákov Hill itself and 3) presence of Strombolian pyroclastic rafts at the Kozákov lava surface may indicate a connection between these volcanic bodies as a feeder and its products. At present, the Prackov cone is separated from the Kozákov lavas by the Lusatian Thrust Fault. These lavas were uplifted up to $300 \mathrm{~m}$ compared to their supposed original position. A relatively young tectonic movement could be traced owing to the evolution of the relief in this area, as only a very slight erosion took place around Prackov cone. On the other hand, the Kozákov lavas were turned into inverse-relief position during the last five million years. The lavas originally filled a palaeo-valley as documented by fluvial gravels buried by lava forming ridges in the present relief (Fediuk 1953; Coubal 1999).

Well-preserved bedded, outward dipping scoriae representing wall facies are exposed in a small abandoned quarry at southern periphery of the Dubolka Hill (location No. 5). The central part of this hill consists of an altered lower crater facies with transition to a vent breccia in the deepest parts of a large abandoned quarry. The quarry exploited a coherent feeder trending E-W. The abundance of Cretaceous marlstone xenoliths increases towards its centre and bottom. Two small "breccia" bodies located north of the Dubolka Hill are massive in texture with chaotic accumulation of scoria fragments,

Tab. 1 List of volcanic edifices in the Jičín scoria cone field

\begin{tabular}{|c|c|c|c|c|c|}
\hline Site & Northing & Easting & Character & Position & Age (Ma) \\
\hline 1 - Prackov & $50^{\circ} 36^{\prime} 19^{\prime \prime}$ & $15^{\circ} 14^{\prime} 42^{\prime \prime}$ & Cinder cone & Solitary & \\
\hline $2-$ Trosky & $50^{\circ} 31^{\prime} 00^{\prime \prime}$ & $15^{\circ} 13^{\prime} 51^{\prime \prime}$ & Cinder cone remnant & Solitary & $16.49 \pm 0.79 *$ \\
\hline 3 - Humprecht & $50^{\circ} 28^{\prime} 13^{\prime \prime}$ & $15^{\circ} 10^{\prime} 12^{\prime \prime}$ & Phreatomagmatic conduit (diatreme) & Solitary & \\
\hline $4-$ Střeleč & $50^{\circ} 29^{\prime} 03^{\prime \prime}$ & $15^{\circ} 15^{\prime} 50^{\prime \prime}$ & Phreatomagmatic conduit (diatreme) & Solitary & $24.6 * *$ \\
\hline 5 - Dubolka & $50^{\circ} 26^{\prime} 59^{\prime}$ & $15^{\circ} 15^{\prime} 02^{\prime \prime}$ & Cinder cone remnant & & \\
\hline $6-$ Houser & $50^{\circ} 26^{\prime} 53^{\prime \prime}$ & $15^{\circ} 16^{\prime} 04^{\prime \prime}$ & Cinder cone remnant & Fissure vent & \\
\hline 7 - Svatá Anna & $50^{\circ} 26^{\prime} 55^{\prime \prime}$ & $15^{\circ} 17^{\prime} 01^{\prime \prime}$ & Strombolian conduit & & \\
\hline $8-$ Veliš & $50^{\circ} 25^{\prime} 01^{\prime \prime}$ & $15^{\circ} 18^{\prime} 52^{\prime \prime}$ & Tuff cone remnant & Solitary & \\
\hline 9 - Čeřovka & $50^{\circ} 26^{\prime} 41^{\prime \prime}$ & $15^{\circ} 21^{\prime} 38^{\prime \prime}$ & Dyke network & Solitary & $20.6 * *$ \\
\hline 10 - Zebín & $50^{\circ} 27^{\prime} 12^{\prime \prime}$ & $15^{\circ} 22^{\prime} 23^{\prime \prime}$ & Tuff cone remnant & Solitary & $17.51 \pm 0.74 *$ \\
\hline $11-$ Železný & $50^{\circ} 28^{\prime} 04^{\prime \prime}$ & $15^{\circ} 23^{\prime} 01^{\prime \prime}$ & Strombolian conduit & Solitary & \\
\hline $12-$ Bradlec & $50^{\circ} 29^{\prime} 22^{\prime \prime}$ & $15^{\circ} 24^{\prime} 52^{\prime \prime}$ & Coherent conduit & Solitary & \\
\hline $13-$ Kumburk & $50^{\circ} 29^{\prime} 36^{\prime \prime}$ & $15^{\circ} 26^{\prime} 45^{\prime \prime}$ & Lava-lake filling phreatomagmatic crater & Solitary & \\
\hline
\end{tabular}

Ages: $*$ - this paper, ${ }^{* *}$ - Lustrino and Wilson (2007), no errors given 


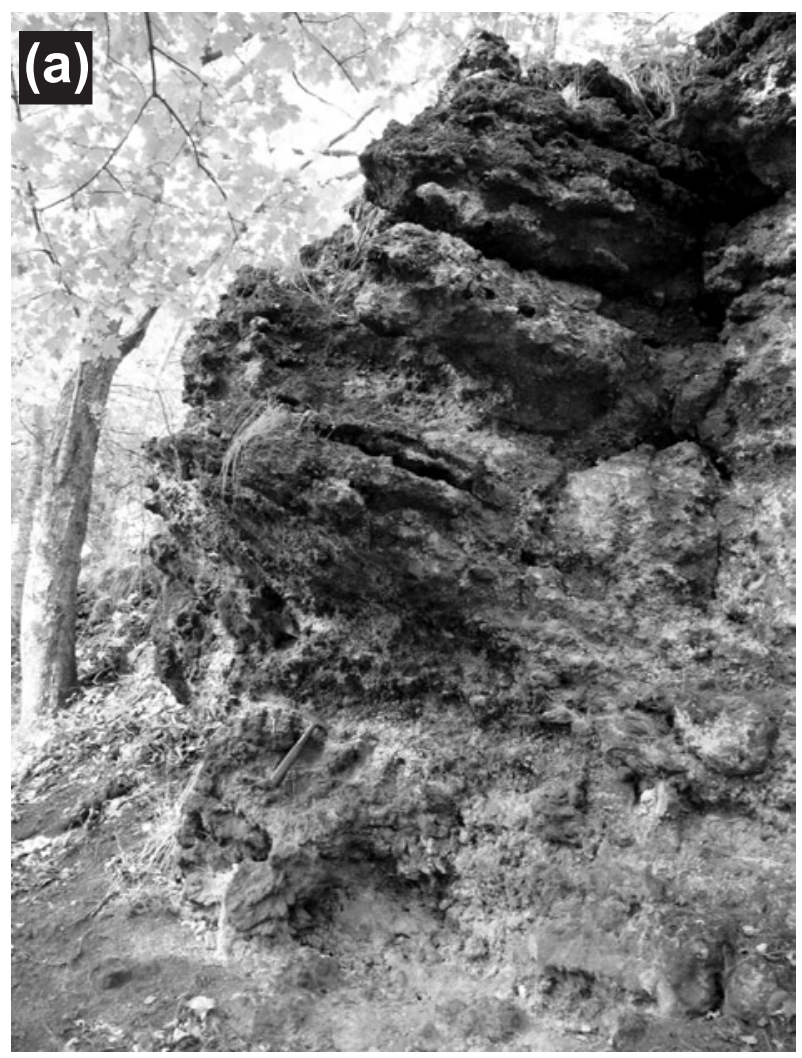

coherent juvenile basaltic fragments and sedimentary xenoliths. Moreover, these breccias are some $400 \mathrm{~m}$ to the north from a fissure along which magma of the Dubolka Hill ascended. The presence of remnants of short-distance scoria flows generated from the Dubolka scoria cone may explain these occurrences.

Non-welded and unaltered, but poorly stratified scoriae are exposed at the Trosky and Houser hills (locations No. 2 and 6). Especially at the Trosky Hill several spindle bombs have been found (Fig. 5), documenting Strombolian style of eruption and a plastic behaviour of larger magma-shreds during ballistic transport. Pyroclastic deposits at both sites are penetrated by coherent feeders; they cause no alteration or caustic effects. On the Trosky Hill, dyke-modified feeder created two plugs utilized in medieval times for construction of impressive fortification (Fig. 2).

At the Zebín Hill (Fig. 6a; location No. 10), two different facies were documented in pyroclastic deposits. The lower part enriched in xenoliths is massive and probably corresponds to a coarse-grained basal phreatomagmatic layer (sensu Schmincke 1977). The content of marlstone xenoliths decreases upwards (from c. $40 \%$ to less than $10 \%$ ). At the top, slight stratification could be documented suggesting a presence of a wall facies relic. Magmatic fragments are only poorly vesiculated and dominated by clasts not exceeding $1 \mathrm{~cm}$ (Fig. 6b). The character of magmatic fragments (i.e. absence of vesiculation and

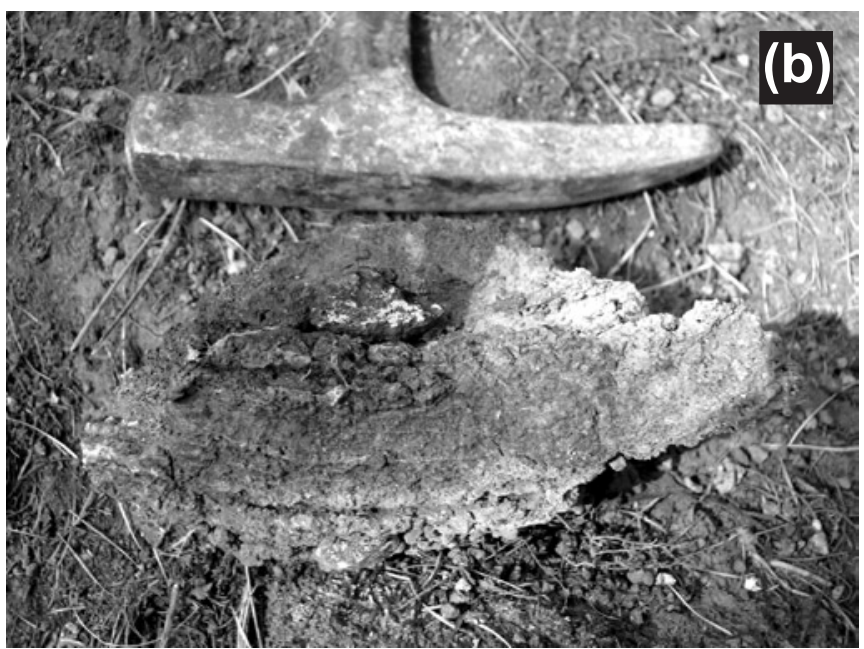

Fig. 4a - non-welded, stratified scoriae of the Prackov cinder cone remnant. $\mathbf{b}$ - fragment of a spindle bomb in pyroclastic deposits of the Prackov Hill.
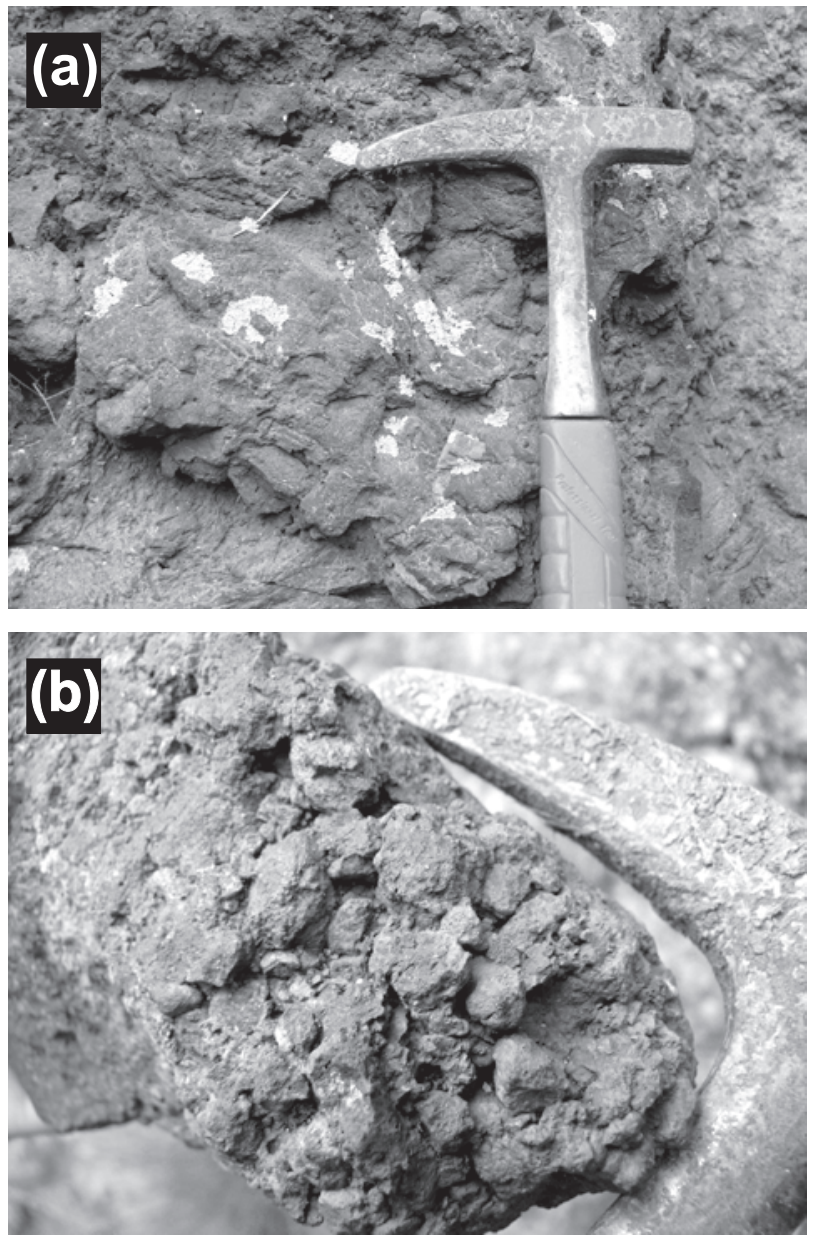

Fig. 5a - spindle bomb in non-welded, non-stratified Strombolian scoriae on the Trosky Hill. $\mathbf{b}$ - non-welded scoriae on the Trosky Hill. 

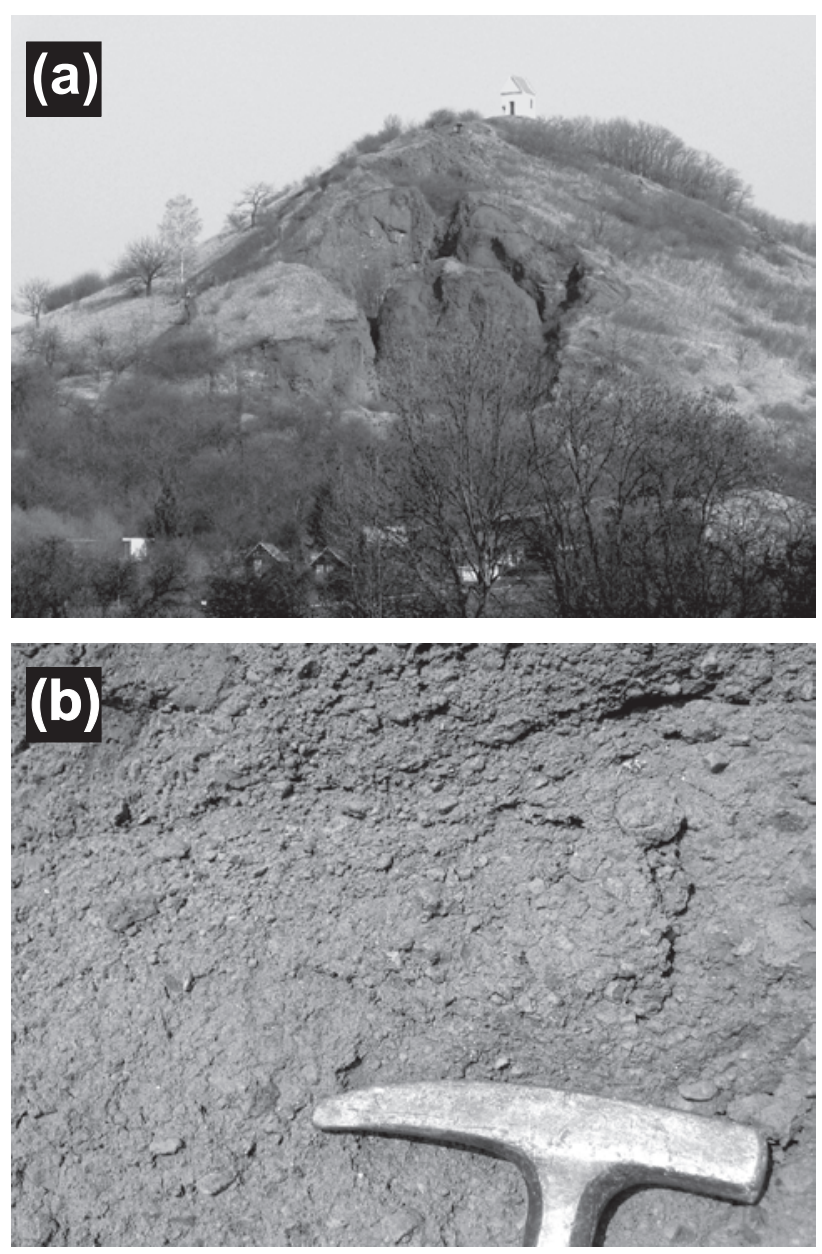

Fig. 6a - remnant of the Zebín cinder cone. Note the abandoned quarry, which exploited a feeder-dyke penetrating the pyroclastic deposits. b - pyroclastic deposits of the Zebín Hill: non- or poorly-vesiculated basaltic fragments with prevailing grain size of $1 \mathrm{~cm}$.

high fragmentation index) suggests quench fragmentation during freatomagmatic eruption. The energy of eruption did not propagate to create a maar crater (sensu Lorenz and Kurszlaukis 2007); but constructed most probably a tuff cone. Similar deposits were observed also at the Veliš Hill (location No. 8). They are massive, intensively altered and represent probably basal wall or lower crater facies affected by near-vent alteration.

Deeper still parts of a volcanic edifice could be seen at the Železný and Střeleč hills (locations No. 11 and 4), where chaotic vent breccias with vertically oriented magma-shreds occur. The first one is dominated by magmatic particles fragmented by magmatic gas dissolution (Fig. 7), whereas the second one is characterised by the presence of abundant xenoliths of Cretaceous sediments fragmented by thermohydraulic shockwaves (Zimanowski et al. 1991, 1995; Lorenz 2007; Lorenz and Kurszlaukis 2007) during phreatomagmatic explosion. With respect to petrography, the Železný Hill was interpreted as a conduit of Strombolian eruption (with slight phreatomagmatic influence), where magmatic gasses dominated the eruption. On the other hand, the Střeleč Hill is viewed as a diatreme penetrated by late magmatic plugs. A vent breccia of predominantly magmatic origin is present also at the Svatá Anna Hill (location No. 7) but with a poor exposure.

There are two more phreatomagmatic conduits in the studied area. Poorly exposed breccia at the Humprecht Hill (location No. 3) is characterized by high fragmentation degree and substantial amount of Cretaceous material suggesting a presence of a diatreme. No further interpretation is possible due to the lack of outcrops with clear relations of breccia fragments. Phreatomagmatic vent breccia (diatreme facies) was also documented at the Kumburk Hill (location No. 13). It is penetrated by a conical body of basanite with 3-D charcoal-mill oriented columnar jointing (Fig. 8). This is interpreted as a lower part of a lava-lake filling a lower level of a phreatomagmatic crater.

Only the coherent feeder remains at the Bradlec Hill (location No. 12) being surrounded by remnants of vent breccia. If this apparatus produced any pyroclastics, these were already eroded.

A network of dykes penetrating Cretaceous marlstones is seen in an abandoned quarry at the Čeřovka Hill (location No. 9). It remains unclear, whether the dykes reached the surface and produced superficial products, or not. Although no pyroclastics (neither superficial nor conduit related) are present at this clearly subsurface body, it was added to the list as one of the few radiometrically dated Miocene volcanics in this region.

Coherent conduits of small volcanoes commonly follow only pre-existing tectonic structures without any influence upon the local stress-field caused by volcanic

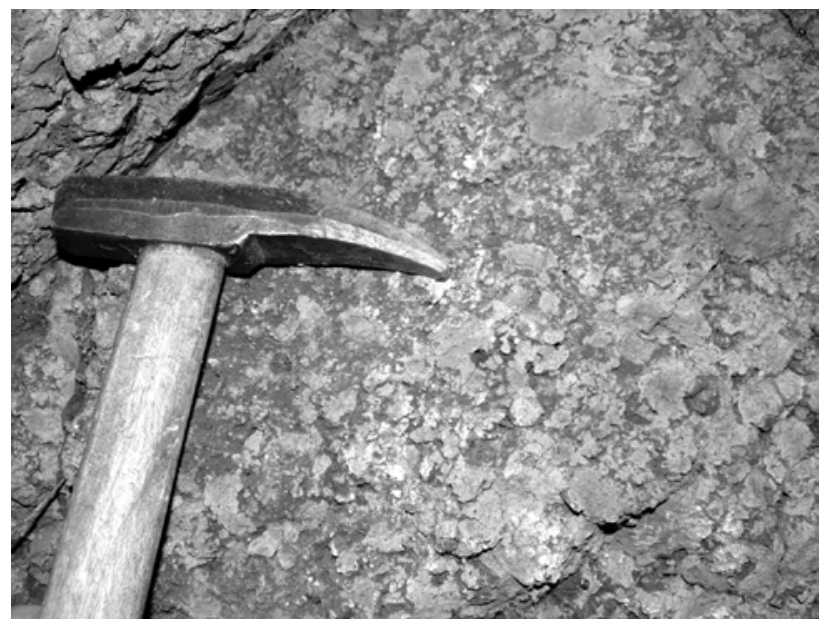

Fig. 7 Vent breccia on the Železný Hill displays chaotic mixture of small- to large-size magmatic shreds with xenoliths of Cretaceous sediments. 


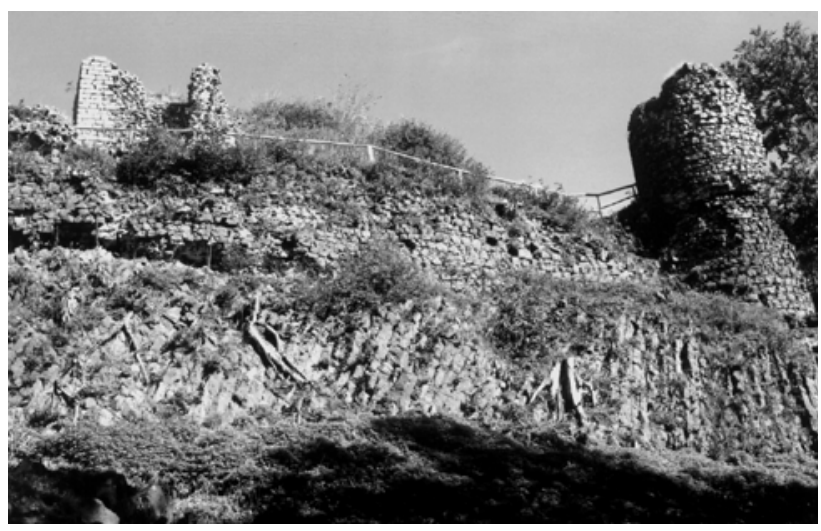

Fig. 8 Fan-like columnar jointing of lava-lake filling phreatomagmatic crater is exposed at Kumburk.

edifice load (Valentine and Krogh 2006). In the studied area, dominantly $\mathrm{E}-\mathrm{W}$ trending fissures were utilized by the magma during its ascent. This position as well as orientation of individual fissures coincides with faults determined by the geological survey (Tíma et al. 1999;
Coubal et al. 1999). The geological setting implies a great role of neotectonics in development of the relief of this area. The interpretation of the observed pyroclastic facies has shown different erosional levels of the studied volcanoes (Fig. 9). If about equal rate of erosion is assumed and age of volcanic activity is known, then the presence of given volcanic facies can be applied for reconstruction of palaeotopography and relief evolution.

\section{Age determinations}

Apart from two pre-existing radiometric data from the studied area (Lustrino and Wilson 2007 - coherent feeder of the Střeleč Hill and dyke of the Čeřovka Hill), coherent feeders of two more edifices (Trosky and Zebín hills) were newly dated using the K-Ar method in ATOMKI laboratories, Debrecen (see Tab. 1). Potassium content in samples (digested in acids and dissolved in $0.2 \mathrm{M} \mathrm{HCl}$ ) was determined by flame photometry with $\mathrm{Na}$ buffer and $\mathrm{Li}$ internal standard. Measurements were checked

\section{Prackov}

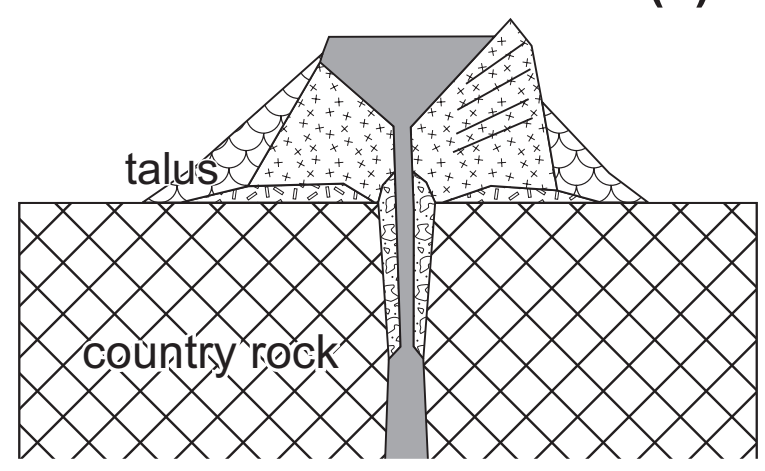

\section{Dubolka}

(b)

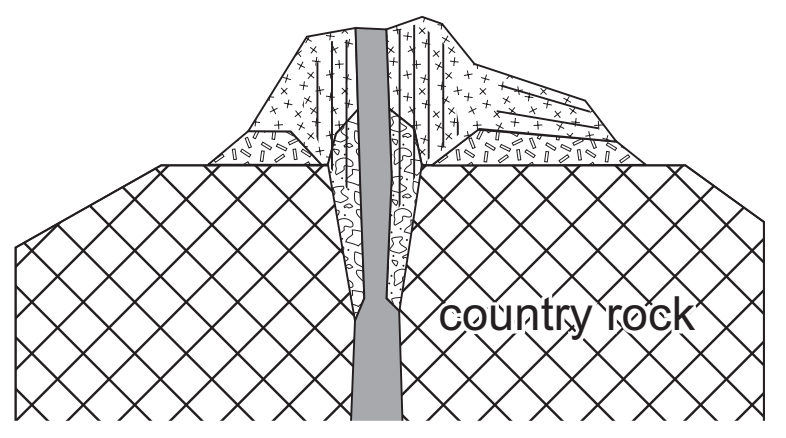

\section{Trosky}

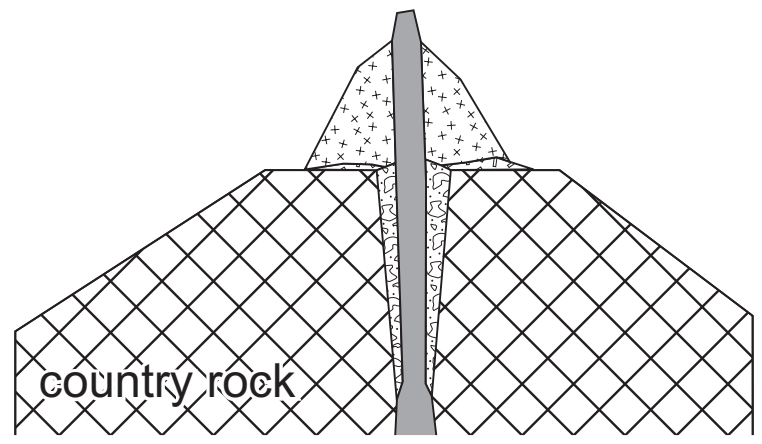

Železný

(d)

Fig. 9 Schematic sections of scoria cones eroded at different levels. a - little eroded scoria cone with preserved upper crater facies, Prackov Hill. b - slightly eroded scoria cone with remnants of wall facies and crater facies passing into vent breccia in the central part, Dubolka Hill. c - moderately eroded scoria cone with relics of superficial facies (basal parts of the wall facies possibly with phreatomagmatic layer), Trosky Hill. d - deeply eroded scoria cone with exposed vent breccia facies, Železný Hill. 
by inter-laboratory standards (Asia 1/65, LP-6, HD-B1 and GL-O). Argon was extracted from samples by RF fusion in Mo crucibles in vacuum. After ${ }^{38} \mathrm{Ar}$-spike addition, gases were cleaned using Ti and SAES getters and liquid nitrogen traps, respectively. The Ar isotopic ratio was measured in the static mode using $15 \mathrm{~cm}$ radius magnetic sector-type mass spectrometer in Debrecen. Balogh (1985) and Odin (1982) described the methods applied in a detail. Age calculations were based on constants proposed by Steiger and Jäger (1977).

The coherent feeder of the Trosky Hill was sampled at the outcrop beneath the eastern tower of the castle and the sample from coherent feeder of the Zebín Hill comes from an abandoned quarry. The obtained data are closely comparable: Trosky $16.49 \pm 0.79 \mathrm{Ma}$ and Zebín $17.51 \pm 0.74 \mathrm{Ma}(2 \sigma)$. These ages correspond to the period, which is characterized by a strong decrease in intensity of volcanic activity in the main volcanic areas of the Bohemian Massif (e.g., Cajz 2000). Both aphyric rocks likely have had a fast and simple cooling history and thus the obtained radiometric data should correspond to crystallization age free of a component of pre-existing pheno- or xenocrysts.

\section{Implications for relief evolution}

A post-eruptive geomorphic evolution of a scoria cone has been studied on examples of Miocene and Pleistocene volcanoes (e.g., Awdankiewicz 2005; Valentine et al. 2006). Combining analyses of scoria cone architecture and K-Ar dating, erosional level of relief $17 \mathrm{Ma}$ ago was reconstructed. In the area of Zebín, pyroclastic deposits covered flat relief with an altitude equivalent to the present $350 \mathrm{~m}$ a.s.l., whereas the present eroded and levelled surface corresponds to $280 \mathrm{~m}$ a.s.l. On the other hand, pyroclastics of the Trosky Hill were deposited at the present level of $420 \mathrm{~m}$ a.s.l., i.e., above the apical plateau of the Český ráj (= Bohemian Paradise) sandstone Rock City, altitude of which varies between 340-380 m a.s.l. A short introduction into local Cretaceous stratigraphy is necessary for a better understanding of post-volcanic relief evolution.

Two monogenetic volcanoes of the Jičín Volcanic Field, for which the ages became available only recently, are set in two distinct geological settings. The impressive Trosky Hill overlooks the Český ráj sandstone Rock City (Teplice Fm.), built of an Upper Turonian delta sediments with maximum thickness of $c .80 \mathrm{~m}$ (Uličný 2001). However, this thickness decreases rapidly towards the rims of the delta body. Finer sediments (e.g., claystones and marlstones) were deposited at its outer margins. Such finer sediments are also preserved in a remnant on the Trosky foothill covering deltaic sandstones with a thickness of some $50 \mathrm{~m}$. The entire sequence in this area was crowned by Middle Coniacian regression sandstones of unknown thickness (reaching or exceeding $100 \mathrm{~m}$ ). The deltaic sandstones were relatively resistant to erosion compared to surrounding marlstones. Moreover they used to be penetrated by basaltic dykes, that often ferruginitized sandstones in their wider surroundings (Adamovič and Cílek 2002) making them thus less susceptible to weathering. The pre-volcanic erosion removed only Middle Coniacian regression sediments in the area of the Trosky scoria cone (at least $100 \mathrm{~m}$ ), whereas postvolcanic erosion removed Lower Coniacian claystones $(50 \mathrm{~m})$ and started to affect apical parts of the Upper Turonian delta body.

The present level of exposure of the Upper Turonian deposits in Jičín and vicinity is approximately $280 \mathrm{~m}$ a.s.l. and the base of pyroclastic deposits of the Zebín Hill is located at $350 \mathrm{~m}$ a.s.l. The difference between the present erosional level of Cretaceous sediments and the base of pyroclastic deposits of the Zebín Hill volcano is up to approximately 70 metres, which corresponds to the post volcanic erosion of the Cretaceous sediments in the Jičín surroundings.

Contact metamorphic rocks - porcelanites - are well known from the studied area. At the Zebín Hill, they form only smaller relics. However, according to uniquely preserved fossils in porcelanites (Fig. 10) from the neighbouring Čeřovka Hill, the stratigraphic interval of deposition of the precursor silty to sandy calcareous marlstones can be determined. The faunal association contains bivalves, larger benthic foraminifera and rare ammonites. Some of them were identified at the species or generic level - i.e. Frondicularia sp., Lithodomus spatulatus Reuss, Tellina sp., Pecten curvatus Geinitz, Inoceramus cf. perplexus, Scaphites geinitzi d'Orbigny etc. Thus, the fauna fully corresponds to that known from typical Upper Turonian localities near Jičín, Železnice and Kněžnice. In lithostratigraphic terms, these sediments belong to the upper (or the uppermost) part of the Jizera Formation.

The complete thickness of the late Turonian marlstone sediments is $80 \mathrm{~m}$ (Malkovský 1974). The thickness of the overlying sediments equivalent to the Český ráj sandstones fluctuates also around 80 metres. The sedimentation probably terminated during Early to Middle Coniacian. The faunal assemblage from porcelanities and the unmetamorphosed marlstones in the close vicinity of volcanoes determines the stratigraphic level to be about 20-30 metres below the sandstone depositional level.

According to biostratigraphic data and sedimentary successions in the neighbouring areas, we can reconstruct the erosional rate, which clearly could not have exceeded $70 \mathrm{~m}$ since the beginning of the volcanic activity in the area $(17 \mathrm{Ma})$. The rates of erosion prior to the volcanic activity are more difficult to estimate, because the com- 


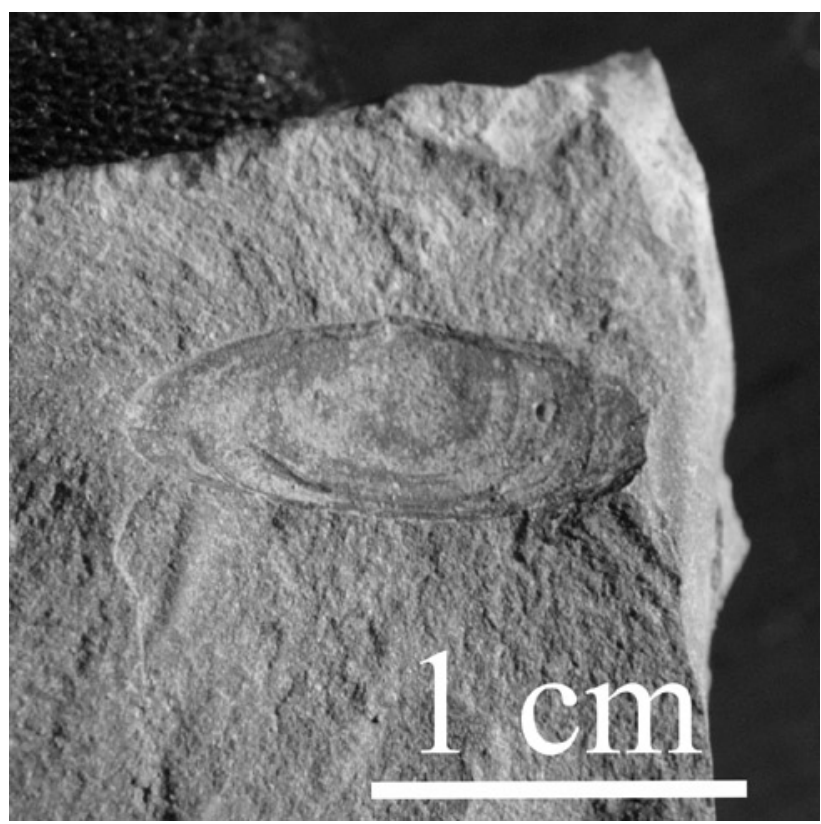

Fig. 10 Uniquely preserved bivalve Tellina sp. in porcelanite of Čeřovka Hill, Upper Turonian.

plete thickness of eroded strata remains little constrained. Nevertheless, if compared to neighbouring areas, at least 150-200 m of Late Turonian and Early to Middle Coniacian sediments had to have been eroded before volcanic activity commenced.

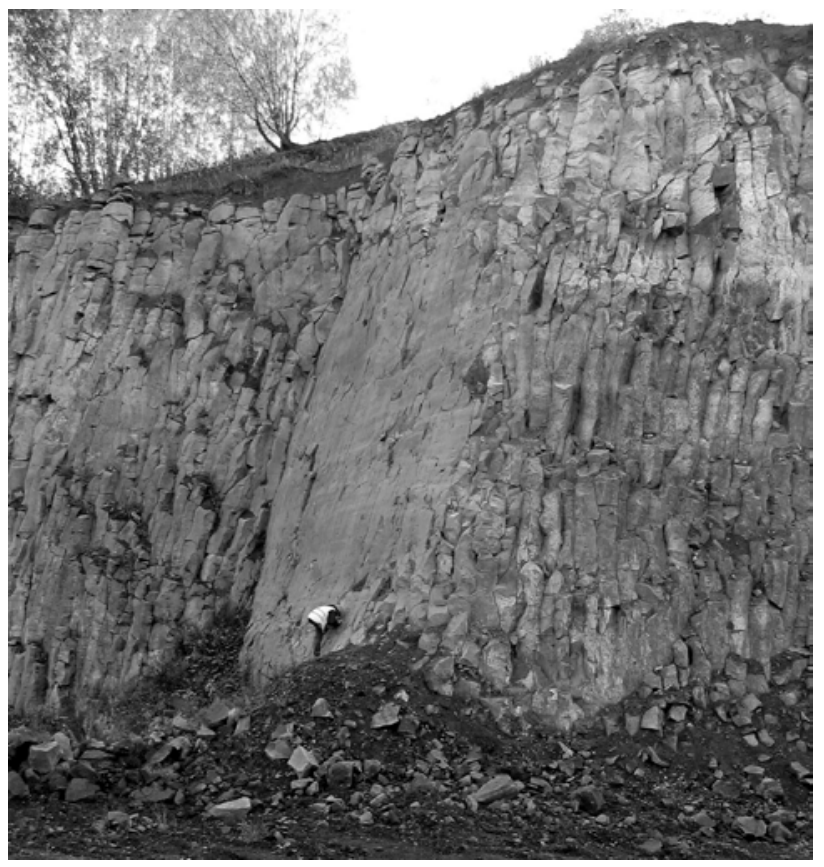

Fig. 11 Fault plane $60 / 64^{\circ}$ with striae documenting an exclusively strike-slip movement in the body of Pliocene Kozákov lavas (Smrčí - working quarry).
The existence of fluvial gravels underlying distal parts of Kozákov lavas (Fediuk 1953; Coubal 1999) provides evidence that these lavas filled a palaeovalley. At present, corresponding parts of lavas form ridges and were uplifted some $300 \mathrm{~m}$ above the supposed source vent at Prackov Hill. Moreover, these lavas flowed towards the northeast (towards the Krkonoše Mts.) and not southwards, where a wide and deep valley along the Lusatian Fault is formed. Hence they do not follow structures responsible for recent geomorphology. This can be explained if the initial lavas were emitted to valleys of different palaeotopography, with only subsequent formation of the depression along the Lusatian Fault. Slow continuous tectonic uplift of the massif with Kozákov lavas along this fault system must have taken place afterwards.

This means that the last tectonic movement on the Lusatian Fault with a vertical displacement of $c .300 \mathrm{~m}$ could have taken place after the lava emission. The movement must have been slow enough to enable antecedent erosion of the "new" Jizera River exposing lavas into recent inverted relief. This event can be dated to approximately $5 \mathrm{Ma}$. The post-Coniacian uplift on this thrust (more than $1 \mathrm{~km}$ ) was combined with less significant strike-slip movements. One of strike-parallel movements on the Lusatian Fault was documented in the Pliocene Kozákov lavas (Fig. 11) and thus must have been also postvolcanic. Furthermore, based on the volcanological criteria as well, the relief prior to this tectonic event can be assumed to having been relatively flat with wide shallow valleys.

\section{Conclusions}

1. Different erosional levels at individual scoria and tuff cones of the Jičín Volcanic Field (NE Bohemia) offer insight into internal structure of monogenetic cones after $17 \mathrm{Ma}$. Thus, this field represents a unique area, where textures of ancient cinder cones could be studied and compared to recent examples.

2. Volcanic activity in the Jičín Volcanic Field was dominated by scattered Strombolian eruptions arranged predominantly along E-W trending faults. Lavas were commonly not emitted, with the exception of the Prackov Hill, supposed feeder of the Kozákov Hill lavas, and possibly the Kumburk Hill. Only few volcanoes in the studied area were phreatomagmatic. Phreatomagmatic eruptions mostly did not propagate forming diatreme-maar volcanoes but they turned into Strombolian eruptions.

3. Most of volcanoes are isolated; only Dubolka, Houser and Svatá Anna Hills together form a fissure vent.

4. Superficial deposits of cinder cones are preserved at several edifices. Therefore, the age data obtained from 
individual apparatuses support the interpretation of relief evolution in the studied area during the Neogene.

5. The highest erosional rate of Cretaceous marine sediments was reached prior to the volcanic activity, during the Palaeogene. Since then, the erosion did not exceed some $70 \mathrm{~m}$ in the area southwest of the Lusatian Fault.

6. An important episode of vertical and, less apparent, strike-slip movements on the Lusatian Fault took place apparently during the last $5 \mathrm{Ma}$, displacing Kozákov lavas and their supposed source vent vertically by some $300 \mathrm{~m}$.

Acknowledgments. Volcanological studies of the Jičín Volcanic Field were carried out within the framework of the project IAA300130612 - "Combined magnetostratigraphic studies of Cenozoic volcanics, Bohemian Massif" supported by the Grant Agency of the Czech Academy of Sciences, which is gratefully acknowledged. Studies ran under Research Plans of individual institutions: AV0Z30130516 (Geological Institute, Academy of Sciences), MZP0002579801 (Czech Geological Survey - research on "Sedimentation and re-sedimentation of volcaniclastics") and MSM0021622855 (Faculty of Science, Charles University). Thanks are also due to the reviewers, Volker Lorenz and František Fediuk, for constructive comments and criticisms. Last but not least, we are grateful to Stanislav Vrána for significant improvement of the English.

Cinder cones of the Jičín Volcanic Field were studied as an integral part of the preparation of the Bohemian Paradise GeoPark natural sites.

\section{References}

Ackerman L, Mahlen N, Jelínek E, Medaris G, Jr., Ulrych J, Strnad L, Mihaljevič M (2007) Geochemistry and evolution of subcontinental lithospheric mantle in Central Europe: Evidence from peridotite xenoliths of the Kozákov Volcano, Czech Republic. J Petrol 48: 2235-2260

Adamovič J, Cílek V (eds) (2002) Ironstones of the Bohemian Cretaceous Basin. Library of the Czech Speleological Society, Vol 38. Zlatý kůň Publishers, Prague, pp 1-172 (in Czech)

AwdAnKIEwicz M (2005) Reconstructing an eroded scoria cone: the Miocene Sośnica Hill volcano (Lower Silesia, SW Poland). Geol Quart 49: 439-448

BALOGH K (1985) K/Ar dating of Neogene volcanic activity in Hungary: Experimental technique, experiences and methods of chronologic studies. ATOMKI Rep. D/1: pp 277-288
Birkenmajer K, Pécskay Z, Grabowski J, Lorenc M, ZAGOZDZON P (2004) Radiometric dating of the Tertiary volcanics in Lower Silesia, Poland. IV. Further K-Ar and Paleomagnetic data from Late Oligocene to Early Miocene basanitic rocks of the Fore-Sudetic Block. Ann Soc Geol Polon 74: 1-19

CAJz V (2000) Proposal of lithostratigraphy for the České středohoří Mts. volcanics. Bull Czech Geol Surv 75: $7-16$

Cas RAF, Wright JV (1987) Volcanic Successions - Modern and Ancient. Allen \& Unwin, London, pp 1-528

Chaloupský J, Prouza V, Tásler R, Kadlec J (eds) (1992) Geological map of the Czech Republic 1:50 000, sheet 03-41 Semily. Czech Geological Survey, Prague

Christensen Ni, Medaris LG Jr., Wang HF, Jelínek E (2001) Depth variation of seismic anisotropy and petrology in Central European lithosphere: A tectonothermal synthesis from spinel Iherzolite. J Geophys Res B: Solid Earth 106: 645-664

Coubal K (ed) (1999) Geological map of the Czech Republic 1:50 000, sheet 03-32 Jablonec nad Nisou. Czech Geological Survey, Prague

Coubal M, Kadlec J, Shrbený O, Křelina J, Opletal M (eds) (1999) Geological map of the Czech Republic 1:50 000, sheet 03-43 Jičín. Czech Geological Survey, Prague

FARSKÝ F (1876) Mineralogische Notizen I. Mineralien aus der Kosakover Basaltkugeln. K kön Geol Reichsanst: 205-208

FEDIUK F (1953) Geology and petrography in the Jizera Valley between Spálov and Bítouchov (Železný Brod area). Sbor Ústř Úst Geol XX: 505-576 (in Czech)

FEDIUK F (1972) Lower-Palaeozoic, Upper-Palaeozoic and Cenozoic volcanics in the area of Železný Brod-Excursion Guide. Charles University, Prague, pp 1-16 (in Czech)

Head JW, Wilson L (1989) Basaltic pyroclastic eruptions: influence of gas-release patterns and volume fluxes on fountain structure, and the formation of cinder cones, spatter cones, rootless flows, lava ponds, and lava flows. J Volcanol Geotherm Res 37: 261-271

Keating GN, Valentine GA, Krier DJ, Perry FV (in print) Shallow plumbing systems for small-volume basaltic volcanoes. Bull Volcanol, DOI 10.1007/s00445-0070154-1

KoneČnÝ P, Ulrych J, Schovánek P, Huraiová M, ŘAnda $Z$ (2006) Upper mantle xenoliths from the Pliocene Kozákov volcano (NE Bohemia): P-T- $f_{2}$ and geochemical constraints. Geol Carpath 57: 379-396

KoPeCKÝ P (1968) Geological-petrographic setting of the Kozákov area. Unpublished MSc. thesis, Charles University, Prague, pp 1-38 (in Czech)

LORENZ V (2007) Syn- and posteruptive hazards of maar-diatreme volcanoes. J Volcanol Geotherm Res 159: 285-312 
LORENZ V, KURSZLAUKIS S (2007) Root zone processes in the phreatomagmatic pipe emplacement model and consequences for the evolution of maar-diatreme volcanoes. J Volcanol Geotherm Res 159: 4-32

Lustrino M, WiLSON M (2007) The circum-Mediterranean anorogenic Cenozoic igneous province. Earth Sci Rev 81: 1-65

Malkovský J (ed) (1974) Geology of the Bohemia Cretaceous Basin and its basement. Nakladatelství ČSAV, Prague, pp 1-262 (in Czech with English summary)

Martin U, NemÉth K (2006) How Strombolian is a "Strombolian" scoria cone? Some irregularities in scoria cone architecture from the Transmexican Volcanic Belt, near Volcán Ceboruco (Mexico) and Al Haruj (Libya). J Volcanol Geotherm Res 155: 104-118

Mikuláš R, Cílek V, Adamovič J (2001) Geological-geomorphological description of rocks-cities in the Bohemian Paradise. Unpublished Report, Archive of the Landscape Protected Area Český ráj, pp 1-43

OdiN GS (ed) (1982) Numerical Dating in Stratigraphy. John Wiley \& Sons, Chichester, New York, Brisbane, pp 1-1040

РАС́́K O (1947) Basaltic rocks in the area between Mladá Boleslav and Jičín. Sbor Stát Geol Úst XIV, Prague, 1-224 (in Czech with Russian and French summaries)

PАCÁK O (1952) The Chemical nature of basaltic rocks in the area of sheet Mladá Boleslav of the map 1:75000. Sbor Ústř Úst Geol XIX: 421-488 (in Czech with English and Russian summaries)

РАС́́K O (1959) Basaltic rocks in the area of sheet Jičín, no. 3855 of the map 1:75 000. Sbor Ústř Úst Geol XXIV: 69147 (in Czech with English and Russian summaries)

RAPPRICH V (2001) Volcanology of the Jičín surrounding. Geoscience Research Reports for 2000: 103-104 (in Czech with English summary)

Risso C, Németh K, Combina AM, Nullo F, Drosina M (2008): The role of phreatomagmatism in a Plio-Pleistocene high-density scoria cone field: Llancanelo Volcanic Field (Mendoza), Argentina. J Volcanol Geotherm Res 169: $61-86$

SchmincKe HU (1977) Phreatomagmatische Phasen in quartären Vulkanen der Osteifel. Geol Jahrb 39: 3-45

SHRBENÝ O (1992) Chemistry of Tertiary alkaline volcanics in the central-western part of the Bohemian Cretaceous
Basin and the adjacent area. Čas Mineral Geol 37: 203-217

Shrbený O, Vokurka K (1985) Current state of the geochronologic and isotopic research of Bohemian Massif neovolcanites and their nodules. Unpublished report, Archive of the Czech Geological Survey, Prague, pp 1-31 (in Czech)

Steiger RH, Jäger E (1977) Subcommission on Geochronology: Convention on the use of decay constants in geo- and cosmochronology. Earth Planet Sci Lett 36: 359-362

Sumner JM, Blake S, Matela RJ, Wolff JA (2005) Spatter. J Volcanol Geotherm Res 142: 49-65

Tíma V, Straka J, Valín F, Shrbený O, KŘelina J (eds) (1999) Geological map of the Czech Republic 1:50 000, sheet 03-34 Sobotka. Czech Geological Survey, Prague

ULIČNÝ D (2001) Depositional systems and sequence stratigraphy of coarse-grained deltas in a shallow-marine, strike-slip setting: the Bohemian Cretaceous Basin, Czech Republic. Sedimentology 48: 599-628

Valentine GA, Krogh KEC (2006) Emplacement of shallow dikes and sills beneath a small basaltic volcanic center - the role of preexisting structure (Paiute Ridge, southern Nevada, USA). Earth Planet Sci Lett 246: 217-230

Valentine GA, Krier D, Perry FV, Heiken G (2005) Scoria cone construction mechanisms, Lathrop Wells volcano, southern Nevada, USA. Geology 33: 629-632

Valentine GA, Perry FV, Krier D, Keating GN, Kelley RE, Cogbill AH (2006) Small-volume basaltic volcanoes: eruptive products and processes, and post-eruptive geomorphic evolution in Crater Flat (Pleistocene), southern Nevada. Geol Soc Am Bull 118: 1313-1330

VanĚČKová M, Holub FV, Souček J, Bowes DR (1993) Geochemistry and petrogenesis of the Tertiary alkaline volcanic suite of the Labe Tectono-volcanic Zone, Czech Republic. Mineral Petrol 48: 17-34

ZimANOWSKI B, FRÖHLICH G, LORENZ V (1991) Quantitative experiments on phreatomagmatic explosions. J Volcanol Geotherm Res 48: 341-358

ZimANOWSKI B, FröHLich G, LoRenz V (1995) Experiments on steam explosions by interaction of water with silicate melts. Nucl Eng Des 155: 335-343 


\section{Rekonstrukce erodovaných miocénních monogenetických strombolských kuželů: studium charakteru vulkanické aktivity jičínského vulkanického pole (sv. Čechy) a odhad rychlosti povulkanické eroze}

Relikty solitérních sopek v severovýchodních Čechách byly nově interpretovány jako zbytky struskových kuželů a jejich přivodních drah. Strombolské erupce bazanitového magmatu, které vystupovalo většinou po východo-západních zlomech, vytvořilo řadu kuželů rozesetých po dané oblasti. Studované vulkány vznikaly strombolskými a freatomagmatickými erupcemi, většinou bez produkce lávových proudů. Vulkanická aktivita probíhala hlavně v období miocénu (24.6-16.5 Ma). U jedné ze studovaných lokalit předpokládáme, že mohla produkovat podstatně mladší lávy Kozákova (6.7-3.5 Ma). Starší strombolské kužely jsou jen slabě postiženy zvětráváním. Intenzita eroze jednotlivých těles závisí na geomorfologické pozici. V některých případech jsou zachovány nespečené, špatně zvrstvené strusky, jinde jsou erozí obnažené bazální povrchové facie nebo svrchní části brekcií př́vodních drah. Interpretace odkrytých facií kombinovaná s radiometrickým datováním přinesla nový náhled na vývoj reliéfu v této oblasti. Eroze kř́idových mořských sedimentů byla zřejmě velice intenzivní v oligocénu, zatímco za posledních 17 milionů let nebylo erodováno více než 70 m sedimentů. Vyplynula též existence mladých (povulkanických) pohybů na struktuře lužického zlomu. Zdokumentován byl laterální pohyb v tělese kozákovských láv a z interpretace současné pozice láv a jejich přepokládané přívodní dráhy vychází vertikální pohyb až 300 m. 